\title{
Effect of irrigation levels and organic compost on okra plants (Abelmoschus esculentus I.) grown in sandy calcareous soil
}

\author{
Abd El-Kader , A.A ${ }^{1}$; Shaaban, S.M ${ }^{2}$ and Abd El-Fattah .M.S. ${ }^{3}$ \\ ${ }^{1}$ Soils and Water Use Deptartment. National Research Centre, Dokki, Cairo, Egypt \\ ${ }^{2}$ Water Relations and Field Irrigation Department, National Research Centre, Dokki, Cairo, \\ Egypt \\ ${ }^{3}$ Plant Nutrition Deptartment.' National Research Centre, Dokki, Cairo, Egypt \\ ABSTRACT
}

\begin{abstract}
Field experiments were conducted on the growing seasons 2008 and 2009 at a private farm located at a newly reclaimed sandy area, El-Saff, Giza governorate, Egypt to evaluate the drip irrigation levels in combination with equal two types of organic fertilizers for an okra crop. The effect of three irrigation levels $1198.8\left(I_{1}\right), 1798.2\left(I_{2}\right)$ and $2397.6\left(I_{3}\right)$ m3/acre with drip in conjunction with two organic fertilizers (composted plant residues and chicken manure at the rate of $6 \mathrm{~m}^{3} /$ acre ) were studied on growth and yield response, using split block design. The results of drip irrigation in conjunction with two types of organic fertilizers were evaluated in terms of growth , yield, water use efficiency and nutrients uptake of the crop. The study indicated that irrigation water quantity $1798.2\left(\mathrm{I}_{2}\right) \mathrm{m} 3 /$ acre met through drip irrigation along with the two types organic fertilizers gave the highest yield (3.3 M g/acre) with 104\% increase in yield as compared to $I_{1}$ and $\mathrm{I}_{3}$. It can be seen that the plant growth and yield were greater in drip with chicken manure as compared to plant residues. The obtained results clear that NPK uptake were significantly affected by water levels and both plant residues and chicken manure. The additional more of irrigation water caused on increase in the uptake of N P K and if compared to the lowest level of irrigation water it increased the growth parameters in expense of okra yield.
\end{abstract}

Keywords: Irrigation, organic fertilization, okra yield, nutrients uptake, Sandy soil.

\section{INTRODUCTION}

Water supply is a major constraint to crop production in the Mediterranean region of Egypt. Efficient use of water by irrigation is becoming increasingly important, and alternative water application methods such as drip and sprinkler, may contribute substantially to the best use of water for agriculture and improving irrigation efficiency. The trend in recent years has been towards conversion of surface to drip irrigation which is considered to be a more efficient delivery system. Scheduling water application is very critical to make the most efficient use of drip irrigation system, as excessive irrigation reduces yield, while inadequate irrigation causes water stress and reduces production. On the other hand, the intensity of the operation requires that the soil water supply be kept at the optimal level to maximize returns to the farmer. High-frequency water management by drip irrigation minimizes soil as a storage reservoir for water, provides at least daily requirements of water to a portion of the root zone of each plant, and maintains a high soil metric potential in the rhizosphere to reduce plant water stress
(Tiwari et al (1998) Singh and Rajput (2007) Al-Harbi et al (2008) Zotarelli et al (2009).

Okra (Abelmoschus esculentum $L$ ) is an annual herb and vegetable crop grown throughout the tropical and subtropical parts of the world either as the sole crop or intercrop with maize or another Emuh et al (2006). Okra plays an important role in the human diet by supplying carbohydrate, protein, fats, minerals and vitamins that are usually deficient in the staple food . The nutritional importance of okra pod has reawakened interest in bringing the crop into commercial production. Despite the nutritional value of okra, its optimum yields (2-3 t ha-1) and quality have not been attained in the tropical countries partly because of a continued decline in soil fertility. Okra plant require warm temperatures and unable to tolerate low temperature for long time or tolerate any threat of frosts. The optimum temperatures are in the range of $21-30^{\circ} \mathrm{C}$, with minimum temperatures of $18^{\circ} \mathrm{C}$ and maximum of $35^{\circ} \mathrm{C}$. Okra is a high water crop use despite having considerable drought resistance. The plant forms a deeply penetrating tap root with dense shallow 
feeder roots reaching out in all directions in the upper $0.45 \mathrm{~m}$ of soil. For high yields, an adequate water supply and relatively moist soils are required during the total growing period. Reduction in water supply during the growing period in general has an adverse effect on yield and the greatest reduction in yield occurs when there is a continuous water shortage until the time of first picking. The period at the beginning of the flowering period is most sensitive to water shortage and soil water depletion in the root zone during this period should not exceed $25 \%$. Water shortage just prior and during early flowering reduces the number of fruits. The effect of water deficit on yield during this period is greater under conditions of high temperature and low humidity. Controlled irrigation is essential for high yields because the crop is sensitive to both over and under irrigation (Al-Harbi et al (2008). The use of plant materials such as wood ash, cocoa husk, rice bran, spent grain and sawdust for improving soil fertility, root growth, pod nutrients and pod yield of okra has not been studied extensively. Decomposing plant residues are reported to release substantial levels of nutrients and organic matter into the soil (Yih-Chi et al (2009). Therefore, apportioned water for agriculture has to be utilized in an efficient and rationalized manner. Two issues that need attention are (1) finding a means of lowering the current level of water use by some efficient water use techniques, and (2) promoting economic return to the farmers in an effort to enhance economic incentives.

This work was carried out to study the effect of plant residues and chicken manure with three levels of irrigation water on growth, nutrients uptake and yield of okra.

\section{MATERIALS AND METHODS}

This research work was undertaken during the growing seasons 2008 and 2009 at a private farm located at a newly reclaimed sandy area, El-Saff, Giza governorate, Egypt. Lays south of Cairo, between $29^{\circ} 38^{\prime} 25.1 \mathrm{~N}$ and $31^{\circ} 19^{\prime} 26.8 \mathrm{E}$, rainfall averages only around 2 to $5 \mathrm{~mm}$ (0.1 to 0.2 in) per year and at intervals of many years. Temperatures average between 13 to $21{ }^{\circ} \mathrm{C}$ in winter. The Khamaseen is a wind that blows from the south in Egypt, usually in spring or summer, bringing sand and dust, and sometimes raises the temperature in the desert to more than $38{ }^{\circ} \mathrm{C}$. The soil was sandy in texture with low fertility and poor in $\mathrm{N}$ content, according soil classification FAO (1970) is regosls. The main analytical data of the soil are presented in Table 1 as determined according to Dewis and
Freitas (1977) and Klute, (1986). Analysis of irrigation water used are presented in Table 2. Regarding their quality, they are classified according to Ayers and westcot, (1976) as no problem water. Chicken manure was bought from local chicken farm. Chemical analysis of organic materials, are shown in Table 3. To find out the effect of different levels of water in combination with constant doses $\left(6 \mathrm{~m}^{3} /\right.$ acre) of composted plant residues or chicken manure on growth and yield of Okra (Abelmoschus esculentus I.) cultivar balady red an experiment was conducted the years 20082009 .

The experiment was laid out in split block design with nine treatments (three levels of irrigation water $1198.8\left(\mathrm{I}_{1}\right), 1798.2\left(\mathrm{I}_{2}\right)$ and $2397.6\left(\mathrm{I}_{3}\right) \mathrm{m} 3 /$ acre and two kinds of organic fertilizers (composted plant residues and chicken manure) at the rate of $6 \mathrm{~m}^{3}$ /acre in addition of control mineral form were applied) each replicated three under trickle irrigation (agro drip). Distance between laterals is $1 \mathrm{~m}$, distance between drippers is $50 \mathrm{~cm}$. Drippers discharge is $2 \mathrm{l} / \mathrm{h}$. Number of drippers/acre are $\simeq$ 8100. Date of planting was 9 February. The plants were thinned to 2 plants around each emitter. Date of the end of fruit picking was 17 July. Therefore, growing season was $\sim 148$ days.

The plots were properly leveled for even and efficient distribution of fertilizers. The fertilizers used as sources of nitrogen, phosphorus and potassium were urea at the rate of $100 \mathrm{~kg} \mathrm{~N} / \mathrm{ha}$, superphosphate $15.5 \%$ at the rate of $90 \mathrm{~kg} / \mathrm{ha}$, and potassium sulfate at the rate of $60 \mathrm{~kg} / \mathrm{ha}$ respectively. Organic amendment were incorporated into the soil two weeks before planting .Nitrogen was applied in two split doses. First dose of $\mathrm{N}$ along with full doses of phosphorus and potassium were applied at the time of sowing, while the remaining half of the nitrogen was applied at flowering stage. Four seeds of early maturing okra were planted per hole at $2 \mathrm{~cm}$ depth Cultural practices such as weeding, hoeing, earthing up, irrigation and sprays against insects pests and diseases were done uniformly in all treatments. During the vegetative growth period, samples of 10 plants were taken at 90 days after sowing and the following parameters were recorded: 1-Plant height $(\mathrm{cm})$., 2-Fresh weight /plant., 3-Number of Branch/plant , 4-Number of leaves, 5-Leaf area , 6-Fresh Pod yield (kg/ acres.) 7-WUE 8- Nutrients uptake of okra leaves. 
At the end of each field experiment soil physical properties were determined according to Dewies \& Freitas, (1977) and Klute, (1986) while chemical analysis according to Cottenie et al., (1982). Data of growth and macronutrient content and soil analysis were subjected to the proper statistical analysis according to the methods of Snedecor and Cochran (1981).

\section{RESULTS AND DISCUSSION}

Effect of different levels of irrigation: The effect of different levels of irrigation on biometric parameters such as plant height, fresh weight, stem diameter, branches number, number of leaves, leaf area per plant, yield $\mathrm{M} \mathrm{g}$ / acre and water use efficiency were analyzed statistically and compared with that of organic fertilizer treatments. The results of these biometric observations for the mean of two years are presented in Table 4. The results of analysis of variance showed that variation among the mean of three replications for all the treatments and all the mean of two years were found to be statistically significant at $5 \%$ level of significance. The analysis of observations showed that different levels of irrigation with drip responded differently to biometric parameters, yield and water use efficiency of okra. The plant height responded significantly with different irrigation levels of drip irrigation reached 70.1 and $96.8 \%$ for $I_{2}$ and $I_{3}$ respectively in compared to $I_{1}$. Irrigation levels had also significant influence on fresh weight was 72.6 and $75.1 \%$ for $I_{2}$ and $I_{3}$, respectively in compared to $I_{1}$. With regard to stem diameter was 105 and $41.2 \%$ for $I_{2}$ and $I_{3}$, respectively in compared to $\mathrm{I}_{1}$, concerning branch number was 77 and $50 \%$ for $I_{2}$ and $I_{3}$ respectively in compared to $I_{1}$. As number of leaves per plant and its leaf area were 30 and $204 \%$ and 191 and 258\% respectively for $I_{2}$ and $I_{3}$ in compared to $I_{1}$. There was a significant increase in the yield in response to drip irrigation treatment at all the levels of irrigation. There was a significant influence of $\mathrm{I}_{2}$ and $\mathrm{I}_{3}$ irrigation supply through drip irrigation requirement by $104 \%$ and $86 \%$ on yield $\mathrm{M}$ g/acre respectively. It can be seen that, the increase of yield with increasing water level at $\mathrm{I}_{2}$ and decreased with increasing water to $I_{3}$ clearing that biometric parameters were increased with increasing water level. Table 4 showed that water use efficiency through drip irrigation resulted higher yield of okra at $I_{2}$ as compared to $I_{3}$.. The results corroborated the findings of ( Alkaff, and Hassan ,2003 Deng et al 2006, Emuh et al ,2006; Metin et al 2006 Singh and Rajput 2007; Al-Harbi et al , 2008 and Abdul naveed et al 2009). its clear from the obtained results in Table 5, that significantly increment in water holding capacity, field capacity and available moisture due to the use of two different types of organic fertilizers. Its increased by $3,11.5$ and $13 \%$ for composted plant residues compared that of untreated soil, in sequence, while it increased by 5,29 and $33 \%$ for chicken manure. maximum values of water holding capacity, field capacity and available moisture were 24.01, 9.25 and $7.89 \%$ at $\mathrm{I}_{2}$ for chicken manure Therefore it can be explain yield increment due to improvement of soil moisture retention and available moisture by applying both composted plant residues or chicken manure (Shaaban, 2006).

Effect of different organic fertilizers: It can be seen that the plant growth and yield were greater in drip with chicken manure as compared to plant residues. Among the different treatments tried, drip with chicken manure responded the highest plant height in all water levels. There were significant influence of chicken manure and plant residues on plant height were 27 and $39 \%$ respectively compared to control. The influence of plant residues and chicken manure were significant on fresh weight by 44 and $51 \%$ respectively compared to the control, stem diameter was influenced by 74 and $111 \%$ by applying plant residues and chicken manure compared to the control, branch number was influenced significantly by 8 and 33\% respectively compared to the control , number of leaves per plant and its leaf area were significantly influenced by 86 $; 112 \%$ and $9 ; 27 \%$ respectively compared to control. It can be seen that green fruit yield of okra was recorded to 17.5 and $29 \%$ for plant residues and chicken manure respectively compared to the control. The significant influence of water use efficiency was 19.5 and $33.0 \%$ for plant residues and chicken manure respectively. Data in Table ( 4 ) showed that the significant interaction effect of different levels of irrigation on biometric parameters such as plant height, fresh weight, stem diameter, branch number, number of leaves, leaf area per plant, yield $\mathrm{M} \mathrm{g/} \mathrm{acre}$ and water use efficiency in combination with organic fertilizer treatments. The beneficial effect of chicken manure on growth and yield of different vegetables was also reported by earlier investigators (AbouHadid, and Sawan ,2003; Rajpaul et al 2004; ElNemer et al 2005; Faten, 2005; Yasmeen et al 2009).

Macro nutrients uptake by okra leaves: Fig. 1 presents the macronutrients uptake of okra leaves under various treatments. There were a significant 
increase in N P and $\mathrm{K}$ uptake of okra leaves in response to drip irrigation treatment at all the levels of irrigation. The obtained results clear that NPK uptake were significantly affected by water level and both plant residues and chicken manure. Regarding to $\mathrm{N}$ uptake, it was influenced by 173 and $273 \%$ for $I_{2}$ and $I_{3}$ in compared to $I_{1}$ and 50 and $106 \%$ for plant residues and organic manure respectively. Phosphorus uptake was recorded that 103 and 213 $\%$ in compared to $I_{1}$ and 44 and $90 \%$ to plant residues and organic manure respectively. Whereas, $\mathrm{K}$ uptake, was 88 and $85 \%$ in compared to $I_{1}$ and for plant residues and organic manure were 56 and $74 \%$ respectively. The presented data in Fig. (1) Showed clearly that, the additional more of irrigation water caused on increase in the uptake of $\mathrm{N} \mathrm{P} \mathrm{K}$ and if compared to the lowest level of irrigation water it increased the growth parameters in expense of okra yield.
Multiple regression analysis between the okra yield $M$ g lacre, soil Available N, P, K, FC and available moisture yielded $R^{2}$ values of 0.89 for the yield. Regression coefficient showing contribution of each soil properties to the okra yield using different levels of irrigation water and organic fertilizers.

$\mathrm{Y}=-131.27-0.40 * \mathrm{~N}+0.79 * \mathrm{P}+0.07 * \mathrm{~K}-112.34$ Av.M+ $98.67 * \mathrm{FC} \quad \mathrm{R}^{2}=0.89$

The obtained equation reviled that okra demonstrated highly significant fruit yield increases with $I_{2}$ of irrigation water which might have been due to an efficient utilization of soil nutrients when irrigation treatments removed the condition of moisture stress in the soil. This was evident from the significant interaction of applied organic fertilizer with the frequency and amount of irrigation. This signaled that irrigation would be more beneficial for okra production under similar soils and agro-ecological conditions ..

Table 1: Analytical properties of El-Saff sandy calcareous soil

1- Mechanical analysis

\begin{tabular}{|c|c|c|c|c|}
\hline \multicolumn{2}{|c|}{ Sand } & \multirow{2}{*}{$\begin{array}{c}\text { Silt } \\
20-2 \mu \%\end{array}$} & \multirow{2}{*}{$\begin{array}{l}\text { Clay } \\
\qquad 2 \mu \%\end{array}$} & \multirow[t]{2}{*}{ Soil texture } \\
\hline $\begin{array}{c}\text { Course } 2000- \\
200 \mu \%\end{array}$ & $\begin{array}{c}\text { Fine } 200-20 \mu \\
\%\end{array}$ & & & \\
\hline 67.5 & 22.8 & 5.0 & 4.7 & Sandy \\
\hline
\end{tabular}

2- Chemical analysis

\begin{tabular}{|c|c|c|c|c|c|c|c|c|c|c|}
\hline \multirow{3}{*}{$\begin{array}{c}\mathrm{pH} \\
1: 2.5\end{array}$} & \multirow{3}{*}{$\begin{array}{c}\mathrm{EC} \\
\mathrm{dSm}^{-1}\end{array}$} & \multirow{3}{*}{$\begin{array}{c}\mathrm{CaC} \\
\mathrm{O}_{3}\end{array}$} & \multirow{3}{*}{$\begin{array}{c}\text { OM } \\
\%\end{array}$} & \multirow{3}{*}{$\begin{array}{c}\text { CEC } \\
\text { Cmole } \\
\mathrm{kg}^{-1}\end{array}$} & \multicolumn{6}{|c|}{ Macro - nutrients (ppm) } \\
\hline & & & & & \multicolumn{3}{|c|}{ Total } & \multicolumn{3}{|c|}{ Available } \\
\hline & & & & & $\mathbf{N}$ & $\mathbf{P}$ & $K$ & $\mathbf{N}$ & $\mathbf{P}$ & K \\
\hline 7.4 & 2.1 & 11.95 & 0.06 & 4.84 & 415 & 738 & 1015 & 32 & 6 & 56 \\
\hline
\end{tabular}

3- Hydrophysical analysis

\begin{tabular}{|c|c|c|c|c|c|c|}
\hline $\begin{array}{c}\text { Bulk } \\
\text { density } \\
\mathbf{k g ~ m}^{-3}\end{array}$ & $\begin{array}{c}\text { Total } \\
\text { porosity } \\
\%\end{array}$ & $\begin{array}{c}\text { Water } \\
\text { holding } \\
\text { capacity* } \\
\%\end{array}$ & $\begin{array}{c}\text { Field } \\
\text { capacity* } \\
\%\end{array}$ & $\begin{array}{c}\text { Wilting } \\
\text { percentage* }\end{array}$ & $\begin{array}{c}\text { Hydraulic } \\
\text { conductivity } \mathbf{~} \\
\text { day }^{-1}\end{array}$ & $\begin{array}{c}\text { Mean diameter of soil } \\
\text { pores } \boldsymbol{\mu}\end{array}$ \\
\hline 1.63 & 38.5 & 22.8 & 7.11 & 1.22 & 7.3 & 16.7 \\
\hline
\end{tabular}

*On dry weight basis.

Table 2: Analysis of irrigation water used

Source pH EC Soluble cations (meq/l)

$\mathrm{Na}^{+} \quad \mathrm{K}^{+} \quad \mathrm{Mg}^{++} \quad \mathrm{Ca}^{++}$

$6.77 \quad 0.95$

$\begin{array}{ll}\text { Well } & 6.77 \\ \text { Adj.SAR }= & 5.06\end{array}$

$\begin{array}{lll}6.0 & 0.15 \quad 6.0\end{array}$

5.2

$\mathrm{Fe}=\operatorname{traces}(<3 p p m)$.

\section{Soluble anions(meq/l)}

$\mathrm{CO}_{3}^{--} \mathrm{HCO}_{3}^{-} \quad \mathrm{Cl}-\mathrm{SO}_{4}$

$\begin{array}{llll}0.02 & 2.6 & 0.4 & 14.33\end{array}$


Agric. Biol. J. N. Am., 2010, 1(3): 225-231

Table 3: The chemical composition of the organic materials used for cultivation of okra

\begin{tabular}{|c|c|c|c|c|c|c|c|c|c|c|c|c|c|}
\hline $\begin{array}{c}\text { Organic } \\
\text { materials }\end{array}$ & $\begin{array}{c}\mathbf{C} \\
\mathbf{( \% )}\end{array}$ & $\begin{array}{c}\mathbf{N} \\
\mathbf{( \% )}\end{array}$ & $\begin{array}{c}\mathrm{C} / \mathbf{N} \\
\text { ratio }\end{array}$ & $\begin{array}{c}\mathbf{P} \\
\mathbf{( \% )}\end{array}$ & \multirow{2}{*}{$\begin{array}{c}\mathbf{K} \\
\mathbf{( \% )}\end{array}$} & $\mathbf{C a}$ & $\mathbf{M g}$ & $\mathbf{N a}$ & $\mathbf{F e}$ & $\mathbf{Z n}$ & $\mathbf{C u}$ & $\mathbf{M n}$ \\
\hline Plant resid. & 18 & 1.53 & 11.8 & 0.51 & 0.48 & 0.30 & 1.50 & 4.3 & 4.60 & 0.83 & 0.16 & 1.70 \\
\hline Chic.Manure & 38.7 & 2.09 & 18.5 & 5.0 & 2.0 & 9.40 & 8.30 & 8.39 & 6.01 & 1.40 & 0.60 & 12.0 \\
\hline
\end{tabular}

Table 4 : Effect of irrigation levels and both plant residues on some growth parameters and yield of okra plant.

\begin{tabular}{|c|c|c|c|c|c|c|c|c|c|}
\hline \multicolumn{2}{|c|}{ Treatments } & \multirow{2}{*}{$\begin{array}{c}\text { Plant } \\
\text { height } \\
\text { cm }\end{array}$} & \multirow{2}{*}{$\begin{array}{l}\text { Fresh } \\
\text { weight } \\
\text { gm }\end{array}$} & \multirow{2}{*}{$\begin{array}{c}\text { Stem } \\
\text { diameter } \\
\text { cm }\end{array}$} & \multirow{2}{*}{$\begin{array}{c}\text { Branches } \\
\text { Number }\end{array}$} & \multirow{2}{*}{$\begin{array}{l}\text { Leaves } \\
\text { Number }\end{array}$} & \multirow{2}{*}{$\begin{array}{l}\text { Leaf } \\
\text { area } \\
\mathrm{cm}^{2}\end{array}$} & \multirow{2}{*}{$\begin{array}{l}\text { Yield M } \\
\text { g IAcre }\end{array}$} & \multirow{2}{*}{$\begin{array}{c}\text { W.U.E } \\
\%\end{array}$} \\
\hline $\begin{array}{l}\text { Water } \\
\text { levels }\end{array}$ & $\begin{array}{l}\text { Organic } \\
\text { fertilizer }\end{array}$ & & & & & & & & \\
\hline$I_{1}$ & $\begin{array}{l}- \\
\mathrm{Pl} \\
\mathrm{ch}\end{array}$ & $\begin{array}{l}30.0 \\
34.4 \\
41.5\end{array}$ & $\begin{array}{l}132.9 \\
135.4 \\
142.0\end{array}$ & $\begin{array}{l}2.4 \\
3.5 \\
4.2\end{array}$ & $\begin{array}{l}1.1 \\
2.3 \\
3.2\end{array}$ & $\begin{array}{l}12.4 \\
15.3 \\
19.4\end{array}$ & $\begin{array}{l}45.9 \\
48.7 \\
51.7\end{array}$ & $\begin{array}{l}1.23 \\
1.68 \\
1.96\end{array}$ & $\begin{array}{l}1.03 \\
1.40 \\
1.63\end{array}$ \\
\hline \multicolumn{2}{|c|}{ Mean } & 35.3 & 136.7 & 3.4 & 2.2 & 15.7 & 48.8 & 1.62 & 1.35 \\
\hline $\mathrm{I}_{2}$ & $\begin{array}{l}- \\
\mathrm{Pl} \\
\mathrm{ch}\end{array}$ & $\begin{array}{l}44.2 \\
66.0 \\
71.0\end{array}$ & $\begin{array}{l}135.3 \\
229.7 \\
242.0\end{array}$ & $\begin{array}{l}2.9 \\
6.5 \\
7.6\end{array}$ & $\begin{array}{l}3.2 \\
2.2 \\
3.3\end{array}$ & $\begin{array}{l}14.3 \\
19.4 \\
21.4\end{array}$ & $\begin{array}{l}121.1 \\
132.2 \\
153.8\end{array}$ & $\begin{array}{l}3.01 \\
3.32 \\
3.56\end{array}$ & $\begin{array}{l}1.67 \\
1.85 \\
1.98\end{array}$ \\
\hline \multicolumn{2}{|c|}{ Mean } & 60.4 & 235.9 & 7.0 & 3.9 & 20.4 & 143.0 & 3.30 & 1.83 \\
\hline$I_{3}$ & $\begin{array}{l}- \\
\mathrm{PI} \\
\text { ch }\end{array}$ & $\begin{array}{l}61.8 \\
71.4 \\
75.8\end{array}$ & $\begin{array}{l}137.4 \\
235.0 \\
241.6\end{array}$ & $\begin{array}{l}2.8 \\
4.2 \\
5.3\end{array}$ & $\begin{array}{l}3.1 \\
3.3 \\
3.2\end{array}$ & $\begin{array}{l}16.4 \\
45.3 \\
50.3\end{array}$ & $\begin{array}{l}143.9 \\
157.6 \\
187.7\end{array}$ & $\begin{array}{l}1.24 \\
1.42 \\
1.53\end{array}$ & $\begin{array}{l}0.52 \\
0.59 \\
0.64\end{array}$ \\
\hline \multicolumn{2}{|c|}{ Mean } & 69.6 & 238.3 & 4.8 & 3.3 & 47.8 & 172.6 & 1.40 & 0.58 \\
\hline \multicolumn{2}{|c|}{$\begin{array}{c}\text { LSD at } 0.05 \\
\text { W.L } \\
\text { O.F } \\
\text { W.I } \times \text { O.F }\end{array}$} & $\begin{array}{l}0.27 \\
0.93 \\
1.60\end{array}$ & $\begin{array}{l}1.77 \\
2.00 \\
5.33\end{array}$ & $\begin{array}{l}0.13 \\
0.17 \\
0.39\end{array}$ & $\begin{array}{l}0.16 \\
0.19 \\
0.48\end{array}$ & $\begin{array}{l}0.21 \\
0.31 \\
0.63\end{array}$ & $\begin{array}{c}18.01 \\
23.18 \\
\text { NS }\end{array}$ & $\begin{array}{l}0.06 \\
0.13 \\
0.19\end{array}$ & $\begin{array}{l}0.04 \\
0.04 \\
0.13\end{array}$ \\
\hline
\end{tabular}

Table 5 : Effect of irrigation levels and organic fertilizer on moisture retention and available moisture in sandy calcareous soil.

\begin{tabular}{|c|c|c|c|c|c|}
\hline \multicolumn{2}{|c|}{ Treatments } & \multirow{2}{*}{$\begin{array}{c}\text { WHC* } \\
\%\end{array}$} & \multirow{2}{*}{$\begin{array}{r}F^{*} \\
\% \\
\end{array}$} & \multirow{2}{*}{$\begin{array}{c}\text { WP* } \\
\%\end{array}$} & \multirow{2}{*}{$\begin{array}{c}\text { Available moisture* } \\
\%\end{array}$} \\
\hline Water levels & Organic fertilizer & & & & \\
\hline \multirow{3}{*}{$\mathrm{I}_{1}$} & - & 22.82 & 7.14 & 1.24 & 5.90 \\
\hline & $\mathrm{PI}$ & 23.52 & 7.96 & 1.28 & 6.68 \\
\hline & ch & 23.99 & 9.21 & 1.34 & 7.87 \\
\hline \multicolumn{2}{|r|}{ Mean } & 23.44 & 8.10 & 1.29 & 6.82 \\
\hline \multirow{3}{*}{$\mathrm{I}_{2}$} & - & 22.84 & 7.16 & 1.25 & 5.91 \\
\hline & $\mathrm{Pl}$ & 23.54 & 7.99 & 1.30 & 6.69 \\
\hline & ch & 24.01 & 9.25 & 1.36 & 7.89 \\
\hline \multicolumn{2}{|r|}{ Mean } & 23.46 & 8.13 & 1.30 & 6.83 \\
\hline \multirow{3}{*}{$I_{3}$} & - & 22.81 & 7.13 & 1.23 & 5.90 \\
\hline & $\mathrm{PI}$ & 23.51 & 7.94 & 1.27 & 6.67 \\
\hline & $\mathrm{ch}$ & 23.97 & 9.18 & 1.33 & 7.85 \\
\hline \multicolumn{2}{|r|}{ Mean } & 23.43 & 8.08 & 1.28 & 6.81 \\
\hline \multirow[t]{3}{*}{ LSD at 0.05} & W.I & NS & NS & NS & NS \\
\hline & O. F & 0.23 & 0.41 & 0.03 & 0.58 \\
\hline & $\mathrm{WI} \times \mathrm{OF}$ & 0.29 & 0.65 & 0.05 & 0.71 \\
\hline
\end{tabular}

\footnotetext{
* on weight basis
} 


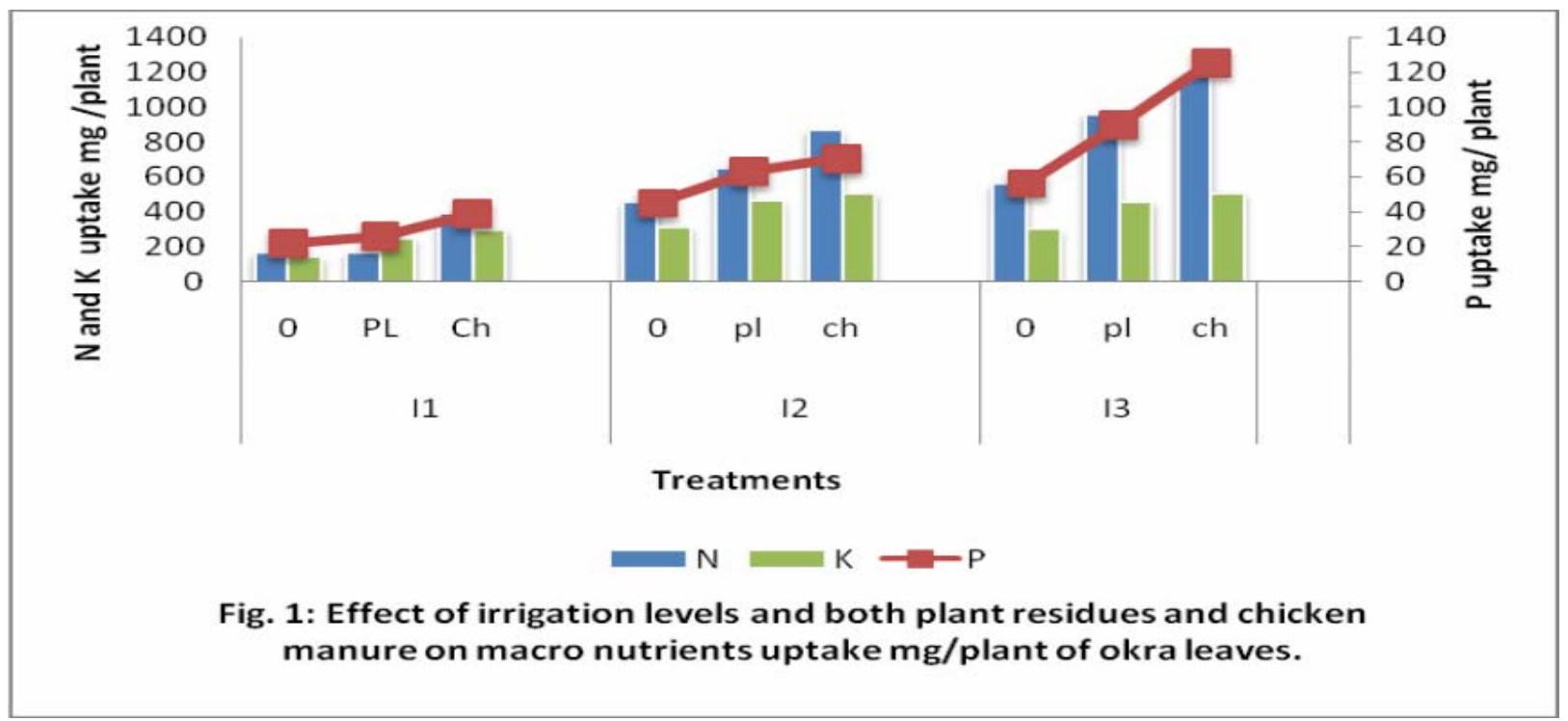

\section{CONCLUSIONS}

Cultivating sandy soil is a promising solution to overcome the fight against hunger especially in the developing countries. The obtained data showed that the significant effect of irrigation levels on biometric parameters such as plant height, fresh weight, stem diameter, branches number, number of leaves, leaf area per plant in combination with organic fertilizer treatments and interaction effect. The use of drip in combination with plant residues and chicken manure can increase the okra yield and water use efficiency significantly at $\mathrm{I}_{2}$ irrigation level. It can be seen that the plant growth and yield were greater in drip with chicken manure as compared to plant residues. The obtained results clear that NPK uptake were significantly affected by water level and both plant residues and chicken manure. The additional more of irrigation water caused an increase in the uptake of $\mathrm{N}$ $\mathrm{P} \mathrm{K}$ and if compared to the lowest level of irrigation water it increased the growth parameters in expense of okra yield

\section{REFERENCES}

Abou-Hadid, A.F. and Sawan O.M. (2003) Effect of inoculation with phosphate-bacteria, sawdust compost and nitrogen sources on okra yield and some properties of calcareous soil. Acta Hort. (ISNS). 608: 85-94

Alkaff,H.A. and Hassan A.A. (2003). Effect of organic fertilizer and foliar application of power 4 on growth and yield of okra plants. University of Aden, J Natural Applied Sc. 7 (1): 25-35
Al-Harbi A.R., Al-Orman A.M and El-Adgham IF.I. (2008) Effect of Drip Irrigation Levels and Emitters Depth on Okra (Abelmoschus esculentus) Growth. J Applied Sci 8 (15): 27642769

Naveed, A, Khan A.A, and Khan I.A. (2009). Generation mean analysis of water stress tolerance in okra (abelmoschous esculentus I.). Pak J Bot. 41(1): 195-205

Anant , B. and R.K. Manohar (2001) Response of okra to biofertilizers. Indian Society of Vegetable Science 28 (2): 197-198

Ayers, R.S. and D.W. Westcot, (1976) Water quality for agriculture.FAO Irrigation and Drainage paper No. 29, 79 pages. Rome.

Doorenbos, J., and W.O., Pruitt, (1977). Guidelines for predicting crop water requirements. Irrigation and Drainage Paper No. 24 (revised), FAO, Rome.

Deng, X.P., Shan, L., Zhang, H., Turner, N.C., (2006). Improving agricultural water use efficiency in arid and semiarid areas of China. Agric. Water Manage. 80, 23-40.

Dewis. J. and F. Freitas, (1970): Physical and chemical methods of soil and water analysis . Soil Bulletin 10, FAO, Rome, 275 pages.

Emuh, IF.N. , A.E. Ofuoku and E. Oyefia (2006) Effect of Intercropping Okra (Hibiscus esclentus) with Pumpkin (Curcubita maxima Dutch ex Lam) on Some Growth Parameters and Economic 
Yield of Maize (Zea mays) and Maximization of Land Use in a Fadama Soil Research Journal of Biological Sciences 1 (1-4): 50-54.

El-Nemer, M.A.; A.M. El-Bassiony and Z.F. Fawzy (2005) Effect of biogen and rhizobacterin biofertilizers on growth, yield and quality of some okra cultivars. Egypt. J. of Appl.Sci., 20 (9) :216226

Faten; H. M. Ismaeil (2005) Effect of some growth regulators on growth and productivity of okra (Abemoschus esculentus L.) plants grown under winter condition. Egypt. J. Agric. Res., 2 (1) : 101-118.

F.A.O (1970) Guidelines to soil description. FAO publ., Rome.

Klute, A.A. (edit), (1986). "Methods of soil analysis", part $1,2^{\text {nd }}$ ed. American Society of Agronomy. Inc., publisher, Madison, Wisconsin, U.S.A.

Metin S. S. , A. Yazar , S. Eker(2006) Effect of drip irrigation regimes on yield and quality of field grown bell pepper. Agricultural Water Management 81 115-131

Rajpaul, A.; A.K. Kapoor; S.K. Sharma and A. Singh (2004) Effect of saline water , FYM and phosphorus on the mineral composition, uptake and yield of different varieties of okra. Annals of Agri.Bio. Research . India 9 (2) 203-211.

Shaaban, S.M., (2006). Effect of Organic and Inorganic Nitrogen Fertilizer on Wheat Plant under Water Regime. Journal of Applied Sciences Research, 2(10): 650-656.

Swain, A.K.; S.K. Pattanayak; M.K. Jana and R.K. Nayak (2003) Effect of integrated use of bio- inoculants and fertilizer nitrogen on growth, yield and nitrogen economy of okra. Indian Society of soil Science, India, 51 (2) : 145-150.

Singh D.K, and T.B.S. Rajput (2007) Response of lateral placement depths of subsurface drip Irrigation on okra (Abelmoschus esculentus.). International Journal of Plant Production 1(1), March

Snedecor , G. W. and Cochran, W. G. (1981) Statistical Methodes 7 th. Ed, lowa State Univ.lowa, USA..

Tiwari K.N. P.K. Mal, R.M. Singh, and A. Chattopadhyay (1998) Response of okra Abelmoschus esculentus $L$. Moench.) to drip irrigation under mulch and non-mulch conditions. Agricultural Water Management 38 91-102

Yih-Chi Tan; Jihn-Sung Lai ; K. R. Adhikari ; S. M. Shakya ; A. K. Shukla and K. R. Sharma (2009) Efficacy of mulching, irrigation and nitrogen applications on bottle gourd and okra for yield improvement and crop diversification. Irrig Drainage Syst 23:25-41

Yasmeen S., Sariah M, Razi I. and Mawardi R. (2009) Bio-Potential of Compost Tea from Agrowaste to Suppress Choanephora 1 cucurbitatrum L. the Causal Pathogen of Wet rot of Okra . Biological Control

Zotarelli L., M.D. Dukes, J.M.S. Scholberg , R. Muñz-Carpena and J. Icerman (2009) Tomato nitrogen accumulation and fertilizer use efficiency on a sandy soil, as affected by nitrogen rate and irrigation scheduling. Agricultural Water Management $96,1247-1258$ 